strengthened this philosophical outlook, and all his future decisions seem to have been made with reference to this concept.

In his choices throughout life fortune favoured him: in his marriage; in surviving the experience of active service in North Africa, Arnhem, and Norway; in joining the editorial staff of the British Medical Journal at a critical time in the development of the National Health Service; in arranging to meet a botanist, Francis Rose, who introduced him to the study of plants in their natural habitat; in his establishment of the British Lichen Society when the Natural History Museum had just appointed a scientist to take charge of its collections; in meeting a kindred spirit in Ursula Duncan; and in accepting an invitation to study the lichens of Uganda and Kenya which resulted in 17 most fruitful years of research recorded in some 30 published papers and gathered together in book form with Hildur Krog as his co-author.

The adventures of these exploits couched in flowing language and punctuated by poetic allusions form the substance of this biography with consummate pen pictures of the co-workers involved. But it would be wrong to think that the author was a passive recipient of these turns of good fortune. 'Fortuna fortes favet' is only part of the whole truth. Persistence of the prepared mind is equally favoured.

Dougal best reveals himself when he writes: 'I delight in the study of natural history because it establishes a sense of kinship with creation. No longer solitary and puzzled, I feel restored to the sea of genes that everywhere casts up living organisms in all their variety of form and function. In analysing their relationships I unconsciously count myself and my friends among them, finding a harmony between us in the matrix of our genetic concordance.'

Only a father of a happy family and a respected member of a close knit community could write in this way. In terms of his own outlook herein possibly lies his crowning achievement. Little wonder that Dougal subscribes to the philosophy of Taoism, the main tenet of which is the unity of all forms of life, a philosophy which appeals to the contemplative and particularly to those for whom the inner life is reality in itself.

STEPHEN MILLER

Vitreous Microsurgery. 2nd Edn. By Steve Charles. Pp. 235. £56.00. Williams and Wilkins: London: 1987.

The second edition of Dr Steve Charles's classic text is an update on his prevous work on decision making in vitreoretinal surgery. The book is aimed at ophthalmologists with an interest (and preferably with a certain amount of experience) in the surgical treatment of retinal disorders.

After outlining the principles of instrumentation in vitreoretinal surgery the author guides us through the intricacies of various types of operations on the vitreous in both the anterior and the posterior segments. Dr Charles makes use of algorithms to illustrate how to anticipate the various events and complications which may arise during complex vitreoretinal surgery. I find this approach helpful, as it enables the surgeon and the theatre staff to be prepared for. and to react quickly to, the often sudden changes in the surgical plan.

The book is divided into chapters on a variety of topics such as proliferative vitreo-retinopathy, epimacular proliferation, trauma, and giant retinal tears. I particularly enjoyed the chapters on surgery for proliferative diabetic retinopathy and for the retinopathy of prematurity, subjects in which the author has particular expertise, having pionecred many of the operations described here. The text is illustrated by a few black-and-white photographs, but the book's real strength lies in the many simple but clear line drawings. These are used to emphasise the author's views on the rights and wrongs of various techniques used in vitreoretinal surgery.

The style of the book is somewhat unusual and in places rather authoritative, but those of us who have the privilege of knowing Steve Charles will appreciate his forthright approach to the subject. I have no hesitation in recommending this book to all colleagues interested in vitreoretinal surgery, and it is a must for all departmental librarics.

Z. J GREGOR

\section{Ocular Circulation and Neovascularization:} Documenta Ophthalmologica Proceedings Series 50. Eds D BenEzra, S J Ryan, B M Glaser, R P Murphy. Pp. 573. £105.00. Kluwer: Dordrecht, Netherlands. 1987.

This volume is a compendium of 88 scientific papers presented at the First Symposium on the Ocular Circulation and Neovascularisation held in Jerusalem. Isracl, in September 1986. Dedicated to the memory of Isaac Michaelson, an early pioneer in this field, the book contains a wide range of clinical and basic scientific papers reflecting the interest of morphologists, physiologists, cell biologists, biochemists, and pathologists as well as ophthalmic physicians and surgeons in the ocular circulation and the phenomenon of neovascularisation.

The text is loosely organised into two parts. The first deals with retinal blood flow and vein occlusion, diabetic retinopathy, retinopathy of prematurity, age related macular degeneration, and some aspects of chronic ocular inflammation. The individual papers are wide ranging, with some inevitable overlap of subject matter. The figures and photographs are mostly of good quality, though more stringent editing would have improved the cohesiveness of the text and avoided numerous and unnecessary errors of spelling and syntax and inaccuracies in the reference sections.

The second part of the book is devoted to ocular vasoproliferation in its many forms, with separate sections on neovascularisation of the cornea, the iris, the angle of the eye, and the retina and choroid. A further chapter considers numerous putative angiogenic factors, their origin, nature, and effects on retinal vascular cells in vivo and in vitro. Arguments for the modulating effects of the retinal pigment epithelium on retinal and choroidal vasoproliferation are rehearsed in some detail but as yet without firm conclusion. The concluding section summarises the views of selected investigators in current concepts of ocular neovascularisa- 
tion and considers likely areas for profitable future research.

Most of the papers in this volume are informative, well presented, and adequately referenced, though much of the material is often a restatement or summary of work published elsewhere. For the reader not fully conversant with this field there are numerous interesting studies and several concise but valuable review articles, particularly those on laser photocoagulation for diabetic macular oedema and the management of choroidal neovascularisation and corneal neovascularisation.

This book will have particular appeal for ophthalmologists specialising in retinal diseases and also provide useful reading and background data for trainee ophthalmologists or basic scientists wishing to embark on investigative work on the ocular circulation and the many as yet unresolved facets of ocular neovascularisation.

DESMOND B ARCHER

A Colour Atlas of Allergy. By William F JaCKSON and Rino Cerio. Pp. 126. £35·00. Wolfe: London. 1988.

This book is the latest in the excellent Wolfe series of simple educational textbooks. Among the wide range of topics covered are basic mechanisms of allergy and investigation of allergic disorders in addition to allergic disorders of the skin, eye, nose, lungs, and gut, and allergic drug reactions. Some chapters describe 'allergy' as just type I hypersensitivity reactions and others incorporate all type I-type IV reactions, which is confusing for the amateur immunologist. Moreover, the inclusion of separate chapters on autoimmune diseases and immunodeficiency syndromes suggest that clinical immunology might have been a more appropriate title.

Professor Easty has contributed the chapter on eye disease. He naturally concentrates, and beautifully illustrates, anterior segment problems, including herpes simplex keratitis because of its increased incidence in atopic subjects.

The hallmark of the book (and the entire series) is the wealth of illustrations and the clarity of the information. After reading the chapter on skin prick tests I thought these were both easy to perform and interpret and perhaps even within the grasp of an ophthalmologist's clinical expertise.

The book includes extensive material covering many clinical specialties all linked by disordered immunity. It is difficult to know who it is aimed at, though undoubtedly all medical students, budding physicians, and curious ophthalmologists would find it both fun and informative.

FI.IYABHTH GRAHAM

Optic Neuritis. Eds. R F Hess and G T Plant. Pp. 310. £35.00. Cambridge University Press: Cambridge. 1986.

The first accurate clinicopathological description of multiple sclerosis in this country came from the pen of a Guy's physician. Dr Moxon, in 1875, and nine ycars later an eminent St Thomas's ophthalmologist, Nettleship. described the first cases of optic neuritis. In the absence of the diagnostic techniques available today, the group of patients described was heterogeneous and included cases of ischaemic papillopathy and syphilis, but most of the patients definitely had optic neuritis, presumably duc to demyelinating disease. This volume celebrates the centenary of Nettleship's description and is the report of collected papers from a meeting held in November 1984.

The chapters lay great emphasis on the pathophysiology and testing of visual function in optic neuritis, but with minimal consideration of the clinical assessment. Thus the opening chapter by Campbell emphasises the value of contrast sensitivity in normal and abnormal vision. There is an interesting chapter on pathogenesis (McDonald) and onc on the neurologist's view of optic neuritis (Herman). The importance of immunological investigation is emphasised (Compston), and this surely will ultimately provide us with an explanation of the cellular events. This is followed by several chapters on the experimental investigation of optic neuritis with psychophysical tests. The experiments on mice have also provided important information and the interesting finding that both fast and slow axonal conduction is accelerated in this condition (Ikeda).

Thus this book provides a useful collection of papers on the scientific investigation of optic neuritis. However, there is little to help an ophthalmologist in the clinic. There is no discussion of colour vision or visual ficld abnormalities. There is no mention of the great mimic of optic neuritis, the sphenoid sinus mucocele, and the section on granulomatous optic neuritis is weak. However, the book is worthy of perusal by the clinical ophthalmologist.

M D SANDERS

\section{Notes}

\section{European Ophthalmic Pathology Society}

The 28th Annual Mecting of the European Ophthalmic Pathology Society was held in Copenhagen (Holte), Denmark on 22-25 May 1989 at the invitation of the Organising Secretary, Professor O A Jensen, assisted by Professor J U Prause. Professor G K Klintworth, of Duke University, Durham U S A and the Verhoeff Society, was the honoured guest. Thirty-two ordinary members of the society also attended the meeting.

The following papers were presented at the scientific meeting: Primary hyperoxaluria (primary oxalosis). (G K Klintworth, U S A). Retinoblastoma in an 'old paticnt (K Arnesen, Norway). Conjunctival epibulbar fibrous histiocytoma with orbital extension (E Balestrazzi. Italy). Malignant lymphoma of the brain with vitreous involvement (M Brihaye-van Geertruyden, Belgium). Epithelioma cuniculatum of the eyclid, caruncle and orbit (A Brini. France). Pigmented epiretinal membrane ( $J$ G Cunha-Vaz, Portugal). Darier's disease and retinitis pigmentosa (a new oculocutancous syndrome?) (B Daiker. Switzerland). Juvenile familial amaurotic idiocy (Spiclmeyer-Vogt) (D de Wolff-Rouendaal, The Netherlands). Macular corneal dystrophy with photophobia (A Garner, $U$ K). 